Proc. Estonian Acad. Sci. Biol. Ecol., 2006, 55, 4, 341-354

\title{
Above-ground production of two willow species in relation to radiation interception and light use efficiency
}

\author{
Ebe Merilo $^{\mathrm{a}, \mathrm{b}^{*}}$, Katrin Heinsoo ${ }^{\mathrm{b}}$, Olevi Kull ${ }^{\mathrm{a}}$, and Andres Koppel ${ }^{\mathrm{b}}$ \\ a Institute of Botany and Ecology, University of Tartu, Lai 40, 51005 Tartu, Estonia \\ ${ }^{\mathrm{b}}$ Institute of Agricultural and Environmental Sciences, Estonian University of Life Sciences, Riia \\ 181, 51014 Tartu, Estonia
}

Received 12 May 2005, in revised form 26 May 2006

\begin{abstract}
The study analysed whether higher above-ground production due to fertilization was associated with increased light interception or higher light use efficiency in an Estonian Salix plantation in 1999-2001. The leaf area index (LAI), effective extinction coefficient, and clumping index differed in two studied Salix species. These parameters varied also largely during the vegetation period and due to different availability of mineral nutrients. The values of seasonally intercepted radiation were rather uniform. Though fertilization had a positive effect on LAI, the leaves of fertilized plots were more clumped, which offset the effect of high LAI in terms of light interception. The annual above-ground production and light use efficiency were higher in fertilized than in control plants. Above-ground production was closely related to light use efficiency, whereas the correlation between above-ground production and seasonally intercepted radiation was weaker.
\end{abstract}

Key words: biomass, clumping index, extinction coefficient, LAI, production, Salix.

\section{INTRODUCTION}

Short rotation forest (SRF) plantations are used for biomass production (Heinsoo et al., 2002) and for phytoremediation of contaminated soils and wastewater (Mirck et al., 2005). Annual wood biomass production of Salix and Populus species may exceed 20 tonnes of dry wood matter per hectare (Heilman et al., 1996; Heinsoo et al., 2002). Crop production is often weakly correlated with leaf photosynthetic rate, while light interception by foliage and hence leaf area index (LAI) and leaf area duration are important productivity determinants (Lawlor, 1995). Recent studies with SRF species also conclude that leaf-level photosynthetic

${ }^{*}$ Corresponding author, ebe.merilo@ut.ee 
rates are often poor selection criteria for potentially high-yielding clones, while stem height and diameter, leaf extension rate, final leaf size, and cell number per leaf may be indicative of yield (Robinson et al., 2004).

According to light conversion analysis, the amount of produced dry matter is linearly related to the amount of radiation intercepted by the canopy (Monteith, 1977). In this analysis, light use efficiency ( $\varepsilon$, the slope of the linear correlation between intercepted radiation and stand biomass) is defined as the efficiency of conversion of light energy into dry matter production (Cannell, 1989). The described approach has been frequently used in production analyses (Cannell et al., 1987; Heilman et al., 1996; Bullard et al., 2002). Light use efficiency of forest stands is usually lower than that of C3 agricultural crops (Cannell, 1989; Ruimy et al., 1994). However, the light use efficiency of fast-growing trees (willow, poplar) used in SRF can be close to $\varepsilon$ estimates for agricultural crops (Cannell et al., 1987; Ceulemans et al., 1992; Heilman et al., 1996).

Decreased crop production in nutrient- or water-limited conditions has been associated with reductions in LAI and radiation interception (Lawlor, 1995). Cannell et al. (1987), however, found that differences in the above-ground dry matter production between two willow stands were caused by differences in $\varepsilon$. Although the variability in LAI was large in that study, radiation interception was not considerably different between two stands. Improved nitrogen availability may increase leaf nitrogen concentration and photosynthetic rate. A clear positive correlation between leaf $\mathrm{N}$ and net photosynthetic capacity has been found for different functional groups of plants (Reich et al., 1998). Light use efficiency depends on photosynthesis, respiration, and canopy structure (Cannell, 1989).

The aim of the present study was to analyse whether higher SRF willow aboveground production due to fertilization is associated with increased light interception or higher light use efficiency. For that, several parameters related to canopy structure and function (LAI, radiation interception, extinction coefficient, clumping index) were determined for two willow species growing under contrasting nutrition conditions. Better understanding of the mechanisms leading to the formation of above-ground production is important for the selection of productive clones and also for optimal management of SRF.

\section{MATERIAL AND METHODS}

The experiment was conducted in a SRF willow plantation located at Saare, eastern Estonia, $58^{\circ} 42^{\prime} \mathrm{N}$ and $26^{\circ} 55^{\prime} \mathrm{E}$, on abandoned agricultural land representing mineral soil of brown Gleyic Podzoluvisol type. The plantation was established in 1993 by using Salix clones originating from The Swedish Energy Forestry Programme. The clone numbers represent the numbering system of the Swedish Salix clones. The planting density was 20000 plants per hectare. The details of the plantation have been described earlier (Heinsoo et al., 2002; Merilo et al., 2004). Two clones, Salix dasyclados Wimm., clone 81090 (further abbreviated as Sd) 
and Salix viminalis L., clone 78183 (Sv) were chosen for the study as they had the most stable and relatively high productivity during the first rotation (Heinsoo et al., 2002). The study was conducted during the second, third, and fourth growth years of the second rotation cycle in 1999, 2000, and 2001, respectively. Four treatments were studied, representing two species $(S v$ and $S d)$ and two fertilization levels. In 1999 and 2000, these treatments were represented by one replicate plot each; and in 2001, by two replicate plots. The fertilized (F) plots were supplied annually with $160 \mathrm{~kg} \mathrm{~N} \mathrm{ha}^{-1}, 37 \mathrm{~kg} \mathrm{P} \mathrm{ha}^{-1}$, and $70 \mathrm{~kg} \mathrm{~K} \mathrm{ha}^{-1}$ during the period 1999-2001. The control (C) plots received no additional fertilizer.

Ten willow shoots per plot were harvested from different stools five times during the summers of 1999 and 2000 at monthly intervals, starting in mid-June. In 2001, four harvests (June-September) were made during the vegetation period. The harvested shoots were selected to cover evenly the whole diameter distribution range within the plot. The shoot diameter at $55 \mathrm{~cm}$ above the ground $(D)$ was measured. This height has been used as a standard for shoot production studies in willow SRF. All leaves were collected from the shoots and dried in an oven $\left(80^{\circ} \mathrm{C}, 48 \mathrm{~h}\right)$. The shoots were dried for 7 days $\left(80^{\circ} \mathrm{C}\right)$.

In July 2000, 10 leaves per plot were collected from 3 different stools along a height gradient and analysed for leaf nitrogen concentration in the Plant Biochemistry Laboratory, Estonian University of Life Sciences, by the standard Kjeldahl method using a TECATOR Kjeltec Auto 1030 analyser.

Power relations between shoot $D$ and its total leaf dry mass $(L)$ were found on the basis of 10 harvested shoots:

$$
L=b * D^{c} .
$$

The diameters of all living shoots with $D \geq 4 \mathrm{~mm}$ of 20-23 sample stools per plot were measured using digital calipers on the day before or after shoot harvest. The sample stools were marked so that the shoot $D$ values of the same stools could be measured during the study. Parameters $b$ and $c$ and shoot diameter data were used to calculate the total leaf mass $(\Sigma L)$ of sample stools. In 1999 and 2000, all living stools per plot were counted to find the actual stool density, while in 2001, the stool density for 2000 was used. In 1999, the stool density was 1.91 , $1.68,1.87$, and 1.63 stools per $\mathrm{m}^{2}$ for $S v \mathrm{C}, S v \mathrm{~F}, S d \mathrm{C}$, and $S d \mathrm{~F}$, respectively. In 2000 , the stool density was $1.89,1.55,1.87$, and 1.66 stools per $\mathrm{m}^{2}$ for $S v \mathrm{C}$, $S v \mathrm{~F}, S d \mathrm{C}$, and $S d \mathrm{~F}$ plots, respectively. To calculate LAI, the following formula was used:

$$
\mathrm{LAI}=\frac{\Sigma L * \mathrm{SLA} * \text { stool density }}{n}
$$

where $n$ is the number of sample stools and SLA is specific leaf area (leaf area/leaf dry mass). The SLA value was determined monthly for one (in 1999) or 
three (in 2000 and 2001) shoots per plot by dividing the shoots into 10 sections of equal length. Three to six fresh leaves per height section were copied by using the standard copying machine in order to determine leaf area. Leaf area was found by scanning the photocopies (Hewlett Packard ScanJet 4C/T) and by calculating the area of the leaf image with the program PINDALA, version 1.0 (designed by I. Kalamees, Eesti Loodusfoto, Tartu, Estonia). Average SLA was used in LAI calculations.

Hemispherical "fish-eye" photographs were taken below the canopy at $50 \mathrm{~cm}$ above the ground in all plots to characterize the light environment. In 1999, three "fish-eye" photographs per plot were taken in August. In 2000 and 2001, five photographs per plot were taken on every harvest date from June to September. Fractional transmission of diffuse irradiance on the horizontal plane $\left(a_{\mathrm{d}}\right)$ was found by the Scanopy (v 2.1A; Régent Instruments Inc., Quebec, Canada) program. The value of $a_{\mathrm{d}}$ is equal to unity above the canopy and to zero in complete shade. The effective extinction coefficient for diffuse radiation $\left(k_{\mathrm{ef}}\right)$ was calculated as:

$$
k_{\mathrm{ef}}=\frac{-\ln a_{\mathrm{d}}}{\mathrm{LAI}} .
$$

In 1999, leaf angles from the lower and upper parts of the canopy were measured on 22 September using a protractor (about 200 leaves per plot). In 2000, leaf angles (about 300 leaves per plot) were measured on $21 \mathrm{July}$; and in 2001, on 22 August (200 leaves per plot). The measured leaf angle distribution of all foliage layers pooled together was fitted using an ellipsoidal function. A parameter $x$ $(x=b / a$, where $b$ is the horizontal semi-axis of the ellipsoid and $a$ is the vertical semi-axis) describes the shape of the distribution for a homogenous canopy (Kull et al., 1999). The theoretical value for the extinction coefficient $\left(k_{\text {the }}\right)$ was determined from the parameter $x$ and the LAI value of the corresponding plot and date as described by Kull et al. (1999). Mean plot clumping index $(\Omega)$ was calculated as (e.g. Chen et al., 1991):

$$
\Omega=\frac{k_{\text {ef }}}{k_{\text {the }}} .
$$

In 2000 and 2001, $k_{\text {ef }}$ for July and August, respectively, was used to calculate $\Omega$. The closer the value of $\Omega$ to zero, the more aggregated is the canopy foliage, while values close to unity refer to a random foliage distribution.

Allometric relations between shoot $D$ and its wood dry mass $(S$; main stem + branches) were found for each plot and harvest date on the basis of 10 harvested shoots:

$$
S=f * D^{g} .
$$


The parameters $f$ and $g$ and shoot $D$ data were used to calculate total wood mass $(\Sigma S)$ of sample stools. Total above-ground dry mass of sample stools was calculated as the sum of $\Sigma L$ and $\Sigma S$.

Annual above-ground production $(P)$ was calculated as the sum of leaf production and stem production for that year. Stem production for 1999, 2000, and 2001 was calculated as the difference in average stool $\Sigma S$ between October 1999 and October 1998, between October 2000 and October 1999, and between September 2001 and October 2000, respectively. In October 1998, 30 shoots per plot were harvested to determine allometric relations between $D$ and $S$, while shoot $D$ values of 20 stools per plot were measured in order to determine the $\Sigma S$ of these stools. Leaf production in 1999, 2000, and 2001 was derived from $\Sigma L$ data for August, July, and July, respectively, when LAI values were at their maximum. For the calculation of $P\left(\mathrm{t} \mathrm{ha}^{-1} \mathrm{y}^{-1}\right)$, the actual plant density values for each plot were used.

To determine light use efficiency, LAI values were first calculated for each day between bud burst (22 April 1999, 20 April 2000, and 24 April 2001) and the final harvest (23 October 1999, 17 October 2000, and 25 September 2001) from the measured LAI values assuming a linear course of LAI between consecutive harvests (see Fig. 1). Data for daily incident short-wave solar radiation $\left(I_{0}\right)$

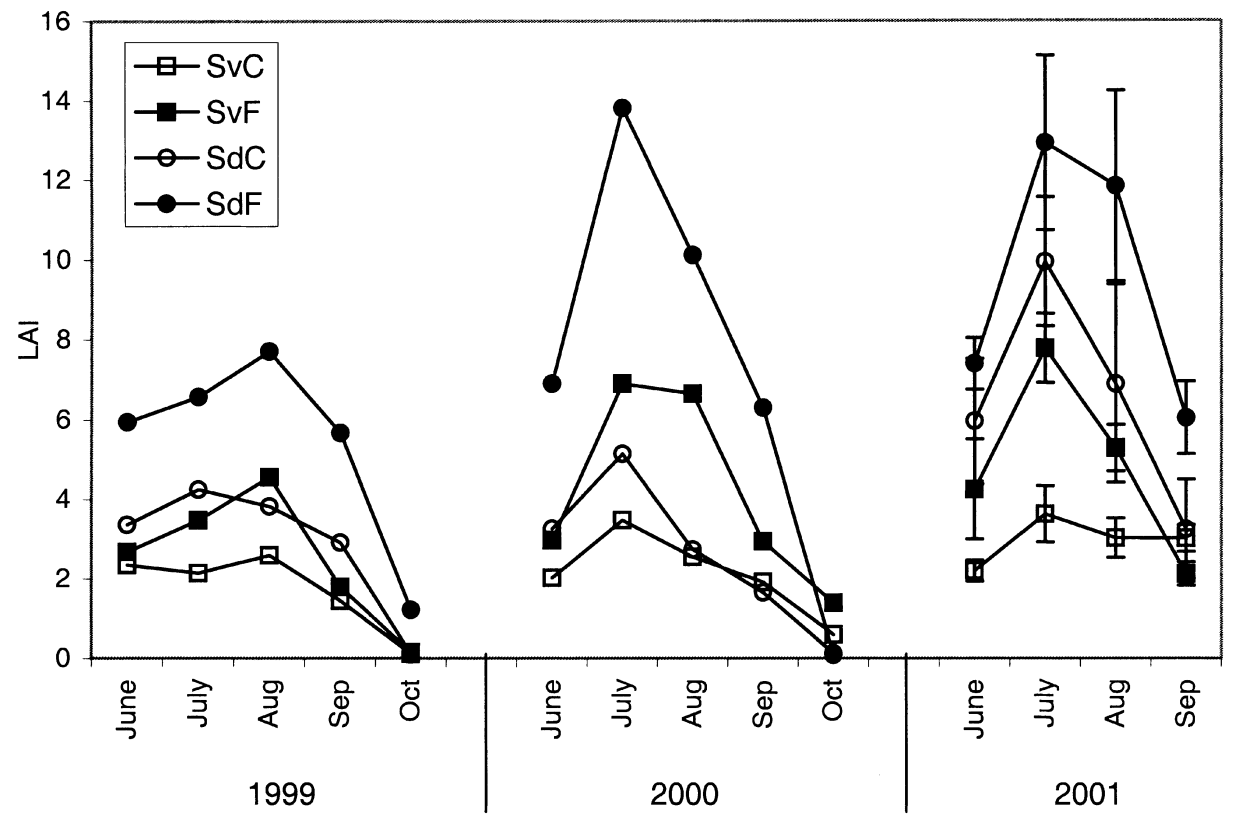

Fig. 1. Seasonal courses of LAI in 1999-2001. For 2001, error bars represent standard errors. Abbreviations: $S v$ - Salix viminalis, $S d$-Salix dasyclados, C - control, F - fertilized. 
were obtained from the Tõravere Meteorological Station situated $60 \mathrm{~km}$ southwest. The light intercepted within the various plots $\left(I_{\mathrm{i}}\right)$ was calculated according to the Lambert-Beer equation as follows:

$$
I_{\mathrm{i}}=I_{0}[1-\exp (-k * \mathrm{LAI})]
$$

In 1999, the $k_{\text {ef }}$ value for diffuse radiation obtained from "fish-eye" photographs in August was used to calculate $I_{\mathrm{i}}$ throughout the season. In 2000 and 2001 , the seasonal course of $k_{\text {ef }}$ was determined and used in the calculation of $I_{\mathrm{i}}$. It has previously been shown that the value of $k_{\mathrm{ef}}$ for diffuse radiation is similar to $k_{\text {ef }}$ for total radiation in Estonian deciduous forests (Kull \& Niinemets, 1998). Daily $I_{\mathrm{i}}$ values were summed in order to find the total amount of intercepted radiation between consecutive harvests. Light use efficiency values were determined as the slopes of linear regression lines between standing live aboveground dry biomass and accumulated intercepted solar radiation.

Statistical analysis was carried out using the computer software package SAS. The effects of different factors were studied using GLM Manova. The multiple comparison of average values was performed with the Least Square Means (LSM) method. Regression significances were controlled with the SAS GLM regression model.

\section{RESULTS}

The LAI values of $S d \mathrm{~F}$ were always the highest and those of $S v \mathrm{C}$ were often the lowest during 1999-2001 (Fig. 1). In 1999, LAI reached a maximum in August, and in 2000 and 2001, in July. In 2001, two plots per treatment were available. For $S d$, particularly $S d \mathrm{C}$, the differences between replicate plots were great, leading to high standard errors. In 2001, LAI of the two studied species was significantly different (all months pooled, $P<0.0001$ ), and the effect of fertilization was marginally significant $(P=0.0501)$. When the data of all years were pooled, the difference in LAI was significant both between the species and the fertilization treatments (Table 1).

Table 1. The effect of species and fertilization on different canopy characteristics when data of all years were pooled (GLM Manova). Values in bold represent high significances $(P<0.05)$, and ns means no significant effect

\begin{tabular}{l|c|c}
\hline & Species & Fertilization \\
\hline LAI & $<\mathbf{0 . 0 0 0 1}$ & $\mathbf{0 . 0 0 1 4}$ \\
$a_{\mathrm{d}}$ & $<\mathbf{0 . 0 0 0 1}$ & $<\mathbf{0 . 0 0 0 1}$ \\
$k_{\mathrm{ef}}$ & $<\mathbf{0 . 0 0 0 1}$ & $\mathbf{0 . 0 0 0 3}$ \\
$P$ & 0.0831 & $\mathbf{0 . 0 0 0 5}$ \\
$I_{\mathrm{i}}$ & 0.0785 & $\mathrm{~ns}$ \\
$\varepsilon$ & $\mathbf{0 . 0 4 0 8}$ & $\mathbf{0 . 0 0 8 6}$
\end{tabular}


In August 1999, the transmittance of diffuse radiation $\left(a_{\mathrm{d}}\right)$, calculated from "fish-eye" photographs, ranged from 0.17 to 0.26 (i.e. radiation interception ranged from $74 \%$ to $83 \%$; Table 2). During the seasons of 2000 and 2001, $a_{\mathrm{d}}$ varied between 0.15 and 0.30 (Fig. 2). The values of effective light extinction coefficients $\left(k_{\text {ef }}\right)$ ranged from 0.24 to 0.53 in August 1999 (Table 2). In 2000 and 2001, seasonal trends in the extinction coefficient were detected: $k_{\text {ef }}$ initially decreased, but increased later during the season (Fig. 2). When the data of all years were pooled, $a_{\mathrm{d}}$ and $k_{\mathrm{ef}}$ were significantly affected by species and fertilization (Table 1 ). In July 2000, leaf nitrogen concentration of fertilized plants was statistically significantly higher (Table $2 ; P=0.0001$ ) than that of unfertilized plants, but there was no difference between the species. The values of the parameter $x$ and theoretical extinction coefficient $\left(k_{\text {the }}\right)$ were not significantly influenced by fertilization and did not differ between the species when the data of three years were pooled (Table 2). Foliage clumping index $(\Omega)$ ranged from 0.16 to 0.60 (Table 2 ) and was significantly influenced by species and fertilization when the data of all years were pooled $(P<0.0001)$.

Figure 3 shows the relationship between the above-ground dry biomass and intercepted accumulated radiation between bud burst and last harvest (October) for the plots examined in 1999 and 2000. The SAS GLM Procedures showed that the fit of linear regression lines was significant at the $95 \%$ level for all plots in 1999 and for $S v \mathrm{~F}$ and $S d \mathrm{~F}$ in 2000 . For $S v \mathrm{C}$ and $S d \mathrm{C}$, the fit of regression lines was higher than $85 \%$ in 2000 . The slopes of the regression lines represent light use efficiency; the values are shown in Table 3. In 2001, similar figures were drawn for 2 replicate plots per treatment (not shown). The values of $\varepsilon$ ranged between 0.36 and $1.09 \mathrm{~g} \mathrm{MJ}^{-1}$ in 2001; average values are shown in Table 3.

Table 2. Foliage parameters in the willow plantation in 1999-2001. Diffuse radiation transmittance $\left(a_{\mathrm{d}}\right)$ and effective light extinction coefficient $\left(k_{\mathrm{ef}}\right)$ for 2000-2001 are presented in Fig. 2. Calculation of these parameters is described in Material and Methods. Abbreviations: Sv - Salix viminalis, Sd - Salix dasyclados, C - control, F - fertilized

\begin{tabular}{|c|c|c|c|c|}
\hline & $\mathrm{SvC}$ & $S v \mathrm{~F}$ & $S d \mathrm{C}$ & $S d \mathrm{~F}$ \\
\hline Diffuse radiation transmittance $a_{\mathrm{d}}(1999)$ & 0.26 & 0.22 & 0.21 & 0.17 \\
\hline Effective light extinction coefficient $k_{\text {ef }}(1999)$ & 0.53 & 0.35 & 0.41 & 0.24 \\
\hline Leaf nitrogen (\%; July 2000) & 2.8 & 3.3 & 2.3 & 3.2 \\
\hline Parameter $x$ (1999) & 2.5 & 4.0 & 3.5 & 3.7 \\
\hline Parameter $x(2000)$ & 2.9 & 2.5 & 3.3 & 2.6 \\
\hline Parameter $x$ (2001) & 3.3 & 2.7 & 3.1 & 3.2 \\
\hline Theoretical value of extinction coefficient $k_{\text {the }}$ (1999) & 0.88 & 0.93 & 0.91 & 0.91 \\
\hline$k_{\text {the }}(2000)$ & 0.89 & 0.85 & 0.90 & 0.84 \\
\hline$k_{\text {the }}(2001)$ & 0.90 & 0.87 & 0.89 & 0.88 \\
\hline Clumping index $\Omega$ (1999) & 0.60 & 0.38 & 0.45 & 0.26 \\
\hline Clumping index $\Omega$ (2000) & 0.46 & 0.27 & 0.34 & 0.17 \\
\hline Clumping index $\Omega$ (2001) & 0.49 & 0.33 & 0.43 & 0.16 \\
\hline
\end{tabular}



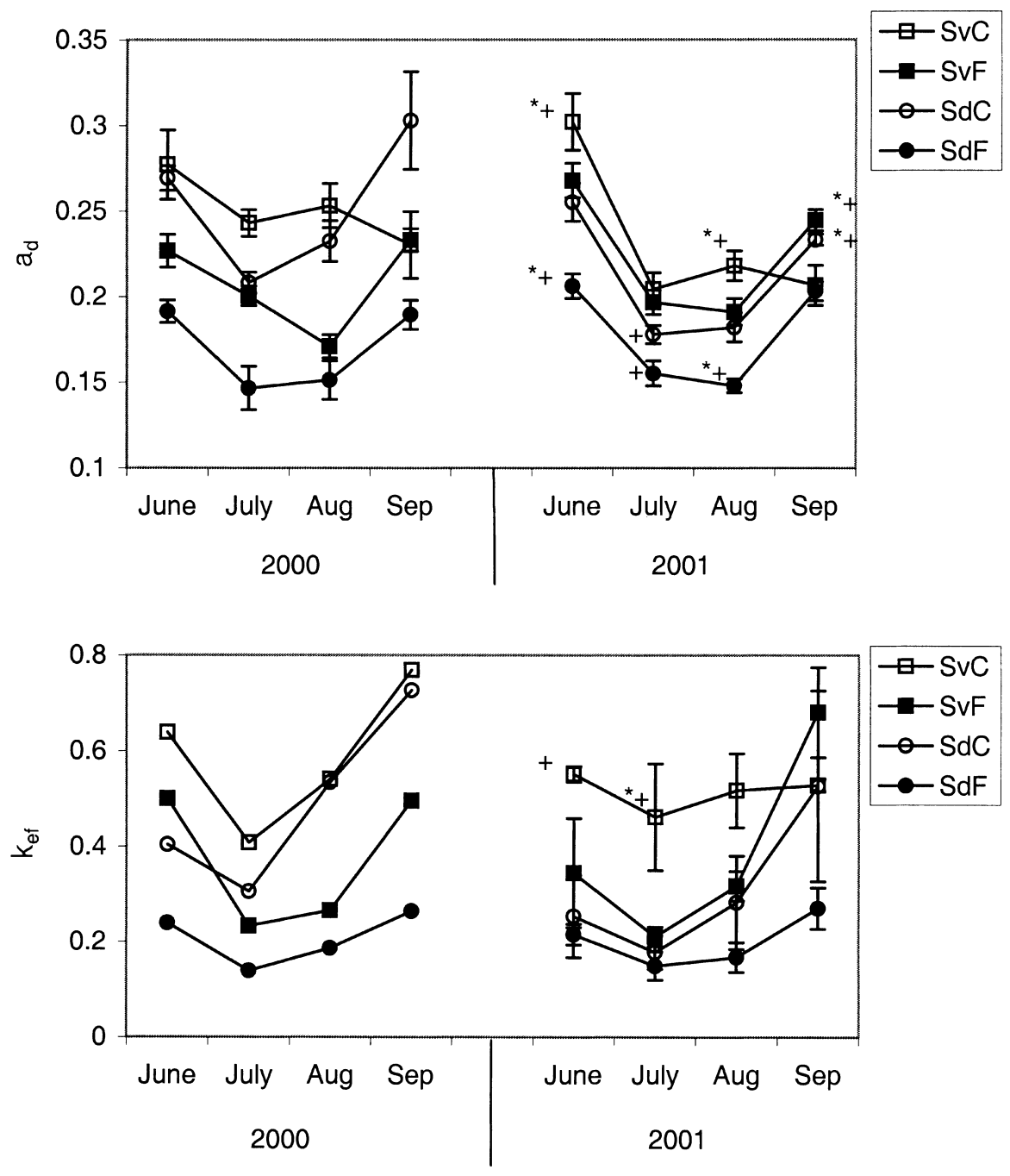

Fig. 2. Seasonal courses of diffuse radiation transmittance $\left(a_{\mathrm{d}}\right)$ and effective extinction coefficient $\left(k_{\mathrm{ef}}\right)$ in 2000-2001. For $a_{\mathrm{d}}$, error bars represent SE of 5 photographs per plot in 2000, but in 2001, they represent SE of 10 photographs made in two replicate plots. * refers to a significant fertilization effect and + refers to a significant species effect in 2001 when two replicate plots per treatment were available. Abbreviations as in Fig. 1.

The fraction of radiation intercepted during the seasons (from bud burst to the last harvest) ranged from $56 \%$ to $68 \%$ (Table 3 ). As the last harvest was made in October in 1999 and 2000 and in September in 2001, the values are not strictly comparable. However, the fraction of radiation intercepted between September and October was small and added only $1-3 \%$ to the seasonally intercepted radiation 

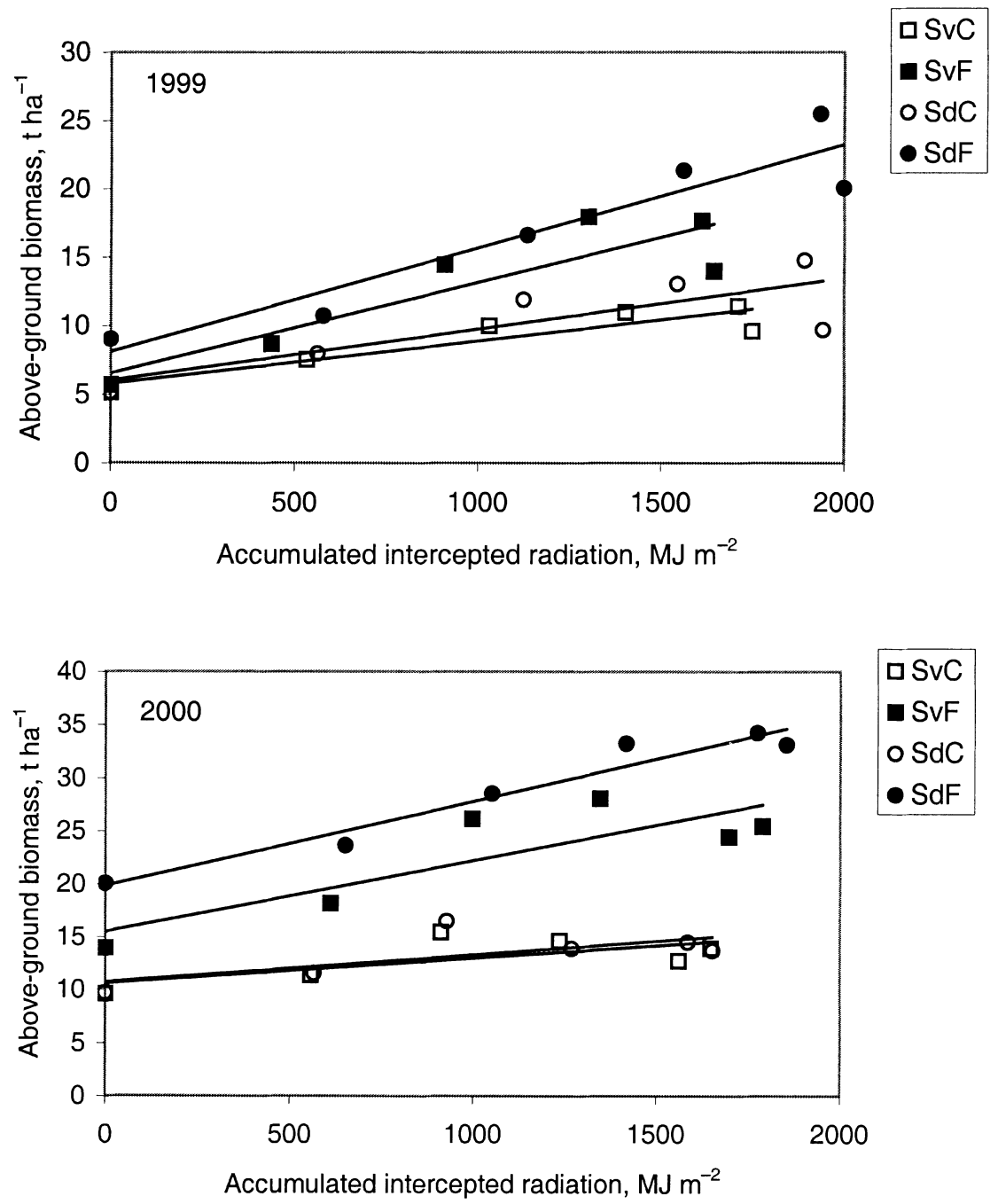

Fig. 3. Relationship between above-ground dry matter and accumulated intercepted radiation between bud burst and October harvest in 1999 and 2000. The slopes of the linear regression lines between above-ground biomass and intercepted radiation represent the values of $\varepsilon$; these are shown in Table 3. Abbreviations as in Fig. 1.

in 1999-2000. The values of light use efficiency were the highest for $S d F$. Table 3 shows that differences in the annual above-ground production and light use efficiency were large, but variation in seasonally intercepted radiation was comparatively small. Statistical analysis of amalgamated data for three years showed that the effect of fertilization on production and $\varepsilon$ was significant, whereas there was no significant fertilization effect on intercepted light (Table 1). 
Table 3. Estimates of annual above-ground production $\left(P, \mathrm{tha}^{-1} \mathrm{y}^{-1}\right)$, fraction of radiation intercepted during the season $\left(I_{\mathrm{i}} / I_{0}\right)$, and light use efficiency $\left(\varepsilon, \mathrm{g} \mathrm{MJ}^{-1}\right)$ in 1999-2001. For 2001, average values and standard errors (in parentheses) are presented. The calculations were based on the whole season from bud burst until last harvest. Abbreviations as in Table 2

\begin{tabular}{l|ccc|c|c|c|c|c|c|c}
\hline & \multicolumn{3}{|c|}{1999} & \multicolumn{3}{c|}{2000} & \multicolumn{3}{c}{2001} \\
\cline { 2 - 10 } & $P$ & $I_{\mathrm{i}} / I_{0}$ & $\varepsilon$ & $P$ & $I_{\mathrm{i}} / I_{0}$ & $\varepsilon$ & $P$ & $I_{\mathrm{i}} / I_{0}$ & $\varepsilon$ \\
\hline \multirow{2}{*}{$S \nu \mathrm{C}$} & 6.2 & 0.59 & 0.31 & 6.2 & 0.61 & 0.24 & 10.7 & 0.62 & 0.73 \\
& & & & & & & $(2.00)$ & $(0.012)$ & $(0.011)$ \\
$S \nu \mathrm{F}$ & 11.2 & 0.56 & 0.66 & 14.6 & 0.66 & 0.67 & 15.9 & 0.64 & 0.87 \\
& & & & & & & $(0.08)$ & $(0.008)$ & $(0.02)$ \\
$S d \mathrm{C}$ & 7.3 & 0.66 & 0.37 & 6.8 & 0.61 & 0.26 & 12.2 & 0.65 & 0.73 \\
& & & & & & & $(6.43)$ & $(0.026)$ & $(0.52)$ \\
$S d \mathrm{~F}$ & 15.0 & 0.68 & 0.76 & 20.0 & 0.68 & 0.80 & 17.7 & 0.68 & 1.05 \\
& & & & & & & $(1.51)$ & $(0.002)$ & $(0.05)$
\end{tabular}

\section{DISCUSSION}

Several important parameters related to canopy structure and function that are used as model inputs or coefficients in various calculations were determined in our study. As an example, $\varepsilon$ is a crucial parameter to estimate production from satellite images (Ruimy et al., 1994) and $\Omega$ is used to derive LAI estimates via optical measurements (Chen et al., 1997). Knowledge regarding species- and fertilization-related variation in these parameters is therefore valuable. The fertilized plots of $S d$ showed the highest LAI during the study. In 2000 and 2001, LAI values exceeding 10 were detected for $S d \mathrm{~F}$ and have previously been reported for SRF poplar stands (Heilman et al., 1996). Our values of $k_{\text {ef }}$, especially in the fertilized plots, were relatively low compared to other broad-leaved stands (Vose et al., 1995), but within a range reported for SRF poplar (Heilman et al., 1996) and willow (Bullard et al., 2002). Ceulemans et al. (1992) concluded that low extinction coefficients may be associated with the relatively large leaf area per shoot of SRF plants. The values of $k_{\text {ef }}$ varied substantially during the season (Fig. 2). Increase in the extinction coefficient later during the growing season observed in our willow plots is common and explained by relatively larger proportion of the radiation intercepted by stems and branches rather than by leaves (Heilman et al., 1996). The variability of $k_{\text {ef }}$ was large; this result is consistent with other reports (Vose et al., 1995).

Chen et al. (1991) concluded that when indirect (optical or radiation) methods are used for LAI measurements, determination of the clumping index is required. Our results indicate that clumping index differs significantly between species and fertility conditions. The values of $\Omega$ also depended on stand age (Table 2). In our experiment, higher LAI resulted from greater leaf area per shoot and stool and was associated with higher degree of foliage clumping. In the situations where higher LAI results from higher stand density, the degree of clumping may 
decrease with increasing LAI (e.g. Bartelink, 1998). The values of both $\Omega$ and $k_{\text {ef }}$ were lowest for $S d \mathrm{~F}$, indicating that foliage clumping and self-shading were greatest in that treatment. Though the seasonal radiation interception was always the highest in the $S d$ F plot (Table 3), the advantage of high LAI in terms of radiation interception was rather small. The seasonal radiation interception for our willow plots was somewhat lower than that found for other deciduous stands (Vose et al., 1995; Bullard et al., 2002). Lower values of radiation interception resulted from low LAI $(S v \mathrm{C})$ or a high degree of foliage clumping $(S d \mathrm{~F})$, or a combination of both. Chen et al. (1997) found that the clumping index was larger shortly after leaf emergence than in the mid-summer, i.e. not fully-grown leaves were less clumped. It is possible that the advantage in light interception offered by higher LAI attained earlier during the season in fertilized plots (particularly in $S d \mathrm{~F}$ ) is underestimated in our calculations because a constant (June) value of $k_{\text {ef }}$ was used when calculating intercepted light from bud burst to the June harvest.

Ruimy et al. (1994) concluded that the values for conversion efficiency are very heterogeneous and could be modelled together with environmental parameters such as water availability, temperature, and soil fertility. Our results confirm the high variability of $\varepsilon$ values and the effect of fertilization (and species) on light use efficiency. The values of light use efficiency ranged from 0.24 to $1.05 \mathrm{~g} \mathrm{MJ}^{-1}$ in our experiment. These values generally agree with $\varepsilon$ estimates found for different Salix species in the UK (Cannell et al., 1987; Bullard et al., 2002), though the 4-fold range is higher than detected by Cannell et al. (1987) and Bullard et al. (2002).

Annual above-ground production was closely related to light use efficiency, but only marginally to intercepted radiation during the season (Fig. 4). The differences in production and light use efficiency were mainly caused by fertilization. Fertilization had a pronounced influence on assimilate allocation in our plantation during the first rotation: the shoot/root ratio was considerably larger in fertilized plots than in the equivalent control plots (Heinsoo \& Koppel, 2002). Thus the positive effect of fertilization on light use efficiency, detected as above-ground biomass produced per unit intercepted radiation (Fig. 3), was partly associated with increased above-ground allocation due to fertilization. Increased light use efficiency due to fertilization may also be associated with increased photosynthetic rate. In 2000, a significant effect of fertilization on leaf nitrogen concentration was detected in both species. Considering that a strong positive correlation exists between leaf nitrogen content and photosynthetic rate (Reich et al., 1998), it is possible that the leaves of fertilized plots photosynthesized at higher rate. However, leaf photosynthetic parameters were studied in these two species in September 2000 (Merilo et al., 2005), with the result that despite the positive effect of fertilization on leaf nitrogen concentration, leaf light-saturated photosynthetic rate and maximal carboxylation rate were not affected due to fertilization. The better nutrient availability resulted in a higher proportion of non-photosynthetic nitrogen in the leaves. As the proportion of leaf non-photosynthetic nitrogen may be higher in 


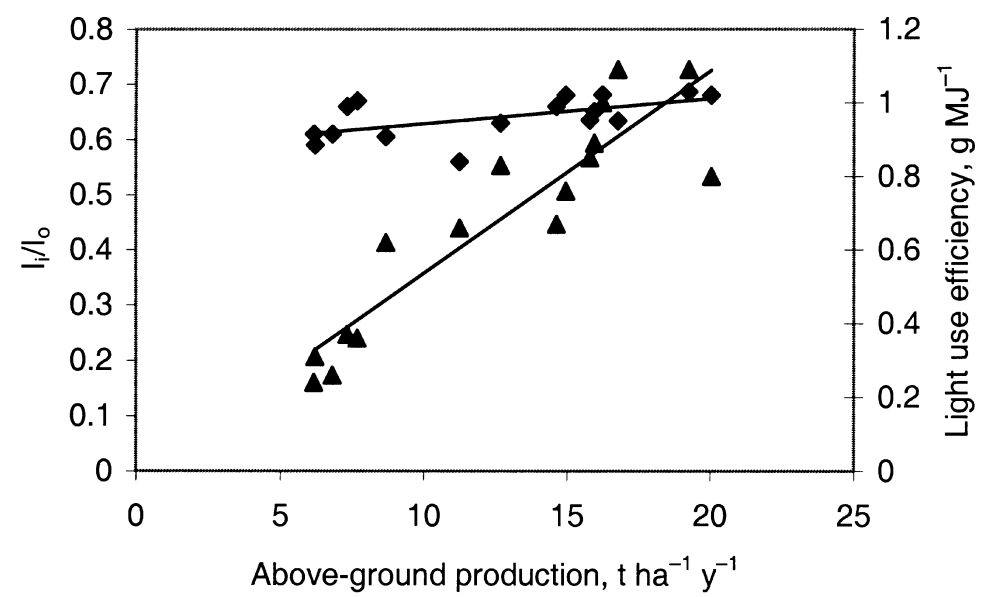

Fig. 4. Relationship between annual above-ground production, $P$, and light use efficiency, $\varepsilon$ (triangles; $R^{2}=0.83, P<0.0001$ ); and between $P$ and intercepted light during the season, $I_{\mathrm{i}} / I_{0}$ (diamonds; $R^{2}=0.34, P=0.0511$ ). Data for both species and fertilization treatments of all years are pooled.

deciduous trees in autumn to ensure nitrogen remobilization before leaf-fall, it is still possible that in June-August the higher leaf nitrogen of fertilized plots was associated with the higher photosynthetic rate.

To conclude, seasonal average LAI was 1.5-2.9 times higher in fertilized plots than in control plots. However, seasonal radiation interception was only marginally related to annual above-ground production because lower $k_{\text {ef }}$ and $\Omega$ values in fertilized plots offset the effect of higher LAI in terms of light capture. Production differences were, on the other hand, closely related to light use efficiency values.

\section{ACKNOWLEDGEMENTS}

The experiment was done during the post-doctoral studies of the corresponding author (grant No. $0361471 \mathrm{~S} 00$ ). The study was partly supported by the Estonian Science Foundation (grants 4831, 5466). We thank Dr. Ain Kallis for providing actinometric data.

\section{REFERENCES}

Bartelink, H. H. 1998. Radiation interception by forest trees: a simulation study on effects of stand density and foliage clustering on absorption and transmission. Ecol. Model., 105, 213-225.

Bullard, M. J., Mustill, S. J., Carver, P. \& Nixon, P. M. I. 2002. Yield improvements through modification of planting density and harvest frequency in short rotation coppice Salix spp. - 
2. Resource capture and use in two morphologically diverse varieties. Biomass Bioenergy, 22, 27-39.

Cannell, M. G. R. 1989. Physiological basis of wood production: a review. Scand. J. For. Res., 4, 459-490.

Cannell, M. G. R., Milne, R., Sheppard, L. J. \& Unsworth, M. H. 1987. Radiation interception and productivity of willow. J. Appl. Ecol., 24, 261-278.

Ceulemans, R., Impens, I., Mau, F., van Hecke, P. \& Chen, S. G. 1992. Dry mass production and solar radiation conversion efficiency of poplar clones. In Biomass for Energy, Industry and Environment (Grassi, G., Collina, A. \& Zibetta, H., eds), pp.157-163. Elsevier Science Publishing, New York.

Chen, J. M., Black, T. A. \& Adams, R. S. 1991. Evaluation of hemispherical photography for determining plant area index and geometry of forest stand. Agric. For. Meteorol., 56, 129 143.

Chen, J. M., Blanken, P. D., Black, T. A., Guilbeault, M. \& Chen, S. 1997. Radiation regime and canopy architecture in a boreal aspen forest. Agric. For. Meteorol., 86, 107-125.

Heilman, P. E., Hinckley, T. M., Roberts, D. A. \& Ceulemans, R. 1996. Production physiology. In Biology of Populus and Its Implications for Management and Conservation (Stettler, R. F., Bradshaw, H. D. Jr., Heilman, P. E. \& Hinckley, T. M., eds), pp. 459-489. NRC Research Press, National Research Council of Canada, Ottawa, ON.

Heinsoo, K. \& Koppel, A. 2002. Biomass distribution in two willow species. In Abstracts International Poplar Symposium III on Basic and Applied Aspects of Poplar and Willow Biology, p. 190. Uppsala, Sweden.

Heinsoo, K., Sild, E. \& Koppel, A. 2002. Estimation of shoot biomass productivity in Estonian Salix plantations. For. Ecol. Manage., 170, 67-74.

Kull, O. \& Niinemets, Ü. 1998. Distribution of leaf photosynthetic properties in tree canopies: comparison of species with different shade tolerance. Funct. Ecol., 12, 472-479.

Kull, O., Broadmeadow, M., Kruijt, B. \& Meir, P. 1999. Light distribution and foliage structure in an oak canopy. Trees, 14, 55-64.

Lawlor, D. W. 1995. Photosynthesis, productivity and environment. J. Exp. Bot., 46, 1449-1461.

Merilo, E., Heinsoo, K. \& Koppel, A. 2004. Estimation of leaf area index in a willow plantation. Proc. Estonian Acad. Sci. Biol. Ecol., 53, 3-13.

Merilo, E., Heinsoo, K., Kull, O., Söderbergh, I., Lundmark, T. \& Koppel, A. 2005. Leaf photosynthetic properties in a willow (Salix viminalis and Salix dasyclados) plantation in response to fertilization. Eur. J. For. Res., 125, 93-100.

Mirck, J., Isebrands, J. G., Verwijst, T. \& Ledin, S. 2005. Development of short-rotation willow coppice systems for environmental purposes in Sweden. Biomass Bioenergy, 28, 219228.

Monteith, J. L. 1977. Climate and efficiency of crop production in Britain. Phil. Trans. R Soc. Lond. B, 281, 277-294.

Reich, P. B., Ellsworth, D. S. \& Walters, M. B. 1998. Leaf structure (specific leaf area) modulates photosynthesis-nitrogen relations: evidence from within and across species and functional groups. Funct. Ecol., 12, 948-958.

Robinson, K. M., Karp, A. \& Taylor, G. 2004. Defining leaf traits linked to yield in short-rotation coppice Salix. Biomass Bioenergy, 26, 417-431.

Ruimy, A., Saugier, B. \& Dedieu, G. 1994. Methodology for the estimation of terrestrial net primary production from remotely sensed data. J. Geophys. Res., 99, 5263-5283.

Vose, J. M., Sullivan, N. H., Clinton, B. D. \& Bolstad, P. V. 1995. Vertical leaf area distribution, light transmittance and application of the Beer-Lambert law in four mature hardwood stands in the southern Appalachians. Can. J. For. Res., 25, 1036-1043. 


\title{
Kahe pajuliigi maapealse produktsiooni seos valguse neeldumise ja selle kasutamise efektiivsusega
}

\author{
Ebe Merilo, Katrin Heinsoo, Olevi Kull ja Andres Koppel
}

Ida-Eestis Saarel asuvas kiirekasvulise paju istanduses uuriti aastail 1999-2001, kas väetamisest tingitud kõrgem maapealne produktsioon tuleneb paremast valguse neeldumisest lehestikus või suuremast valguse kasutamise efektiivsuskoefitsiendist väetatud ruutudel. Selgus, et lehepinna indeks (LAI), efektiivne ekstinktsioonikoefitsient ja lehestiku agregatsiooni indeks varieerusid suures ulatuses liigiti (Salix viminalis ja $S$. dasyclados) ja väetustasemeti (kontroll- ja väetatud ruudud), samuti vegetatsiooniperioodi jooksul. Samas oli kogu vegetatsiooniperioodi jooksul lehestikus neeldunud valguse koguhulk uuritud ruutudel üsna sarnane. Kuigi väetamine tõstis LAI-d, oli väetatud ruutude lehestik rohkem agregeerunud ja see annuleeris kõrge LAI võimaliku positiivse mõju valguse neeldumisele. Aastane maapealne produktsioon ja valguse kasutamise efektiivsuskoefitsient olid väetatud ruutudel kõrgemad, võrreldes vastavate kontrollruutudega. Seega võib öelda, et maapealne produktsioon oli positiivses korrelatsioonis valguse kasutamise efektiivsuskoefitsiendiga, kuid seos maapealse produktsiooni ja vegetatsiooniperioodi jooksul lehestikus neeldunud valguse vahel oli nõrk. 